\title{
PENGELOLAAN LKP PADA MASA PENDMIK COVID-19
}

\author{
Zhahara Yusra', Rufran Zulkarnain ${ }^{2}$, Sofino3 \\ 1Zhahara Yusra, Universitas Bengkulu, Indonesia, zhaharayusra99@gmail.com \\ ${ }^{2}$ Rufran Zulkarnain, Universitas Bengkulu, Indonesia, rufran@unib.ac.id \\ 3 Sofino, Universitas Bengkulu, Indonesia, sofino@unib.ac.id
}

\begin{abstract}
The purpose of this study was to determine and describe in detail the management of LKP during the pandemic. This research is a qualitative descriptive research. This study uses interview data collection techniques, observation, and documentation. Data validity checking used time triangulation, subject triangulation and technical triangulation. The result of the research was that in the process of curriculum adjustment involving Mrs. Rosilah as the head of the LKP, Mr. Erwin as the curriculum organizer and Mrs. Leni Susanti as the tutor, curriculum adjustments were made in the form of dividing study groups into $2 \mathrm{x}$ a week, there was no change in instructors in the learning process, changes working hours in accordance with face-to-face changes, and the application of health protocols in the face-to-face learning process and during the implementation of competency exams.
\end{abstract}

\section{Keywords: LKP Management, Covid-19 Pandemic}

\section{Addresscorrespondence:}

Jl.W.R.Supratman,KandangLimun,MuaraBangkaHulu, KotaBengkulu,Bengkulu38371 


\section{PENDAHULUAN}

Perencanaan adalah proses yang sistematis dalam pengambilan keputusan tentang tindakan yang akan dilakukan pada waktu yang akan datang. Pengorganisasian adalah aktifitas melayani proses kegiatan untuk mencapai tujuan yang telah ditetapkan. Penilaian adalah upaya pengumpulan infromasi mengenai suatu program, kegiatan, atau proyek. Informasi tersebut berguna bagi pengambilan keputusan seperti untuk penyempurnaan suatu kegiatan lebih lanjut, penghentian suatu kegiatan, atau penyebarluasan gagasan yang mendasari suatu kegiatan. Sesuai dengan pendapat Sudjana (2004 : 57), menyatakan bahwa : manajemen pengelolaan meliputi perencanaan, pengorganisasian dan penilaian.

Pendapat Sudjana mengemukakan secara umum tentang bagaimana tahap-tahap pengelolaan yang dilaksanakan di suatu lembaga dengan memulai perencanaan pada tahap awal, pengorganisasian dan dengan diakhiri dengan proses evaluasi atau penilaian. Pengelolaan sangat dibutuhkan dalam memajukan suatu Lembaga, agar kegiatan dalam Lembaga dapat berjalan dengan lancar. Pengelolaan bisa diartikan juga sebagai manajemen atau perencanaan. Pada dasarnya lembaga kursus dan pelatihan juga tidak lepas dari suatu pengelolaan.

Menurut Ikram (2012: 01) bahwa: "Lembaga Kursus dan Pelatihan (LKP) adalah salah satu bentuk satuan Pendidikan Nonformal yang diselenggarakan bagi masyarakat yang memerlukan bekal pengetahuan, keterampilan, kecakapan hidup, dan sikap untuk mengembangkan diri, mengembangkan profesi, bekerja, usaha mandiri, dan atau melanjutkan pendidikan ke jenjang yang lebih tinggi."

Lembaga Kursus dan Pelatihan (LKP) merupakan salah satu satuan pendidikan nonformal yang menyelenggarakan pendidikan kecakapan hidup. Dalam UU RI tentang Sistem Pendidikan Nasional N0. 20 Tahun 2003 pasal 26 tentang pendidikan nonformal ayat (5):

"kursus dan pelatihan diselenggarakan bagi masyarakat yang memerlukan bekal pengetahuan, keterampilan, kecakapan hidup, dan sikap untuk menhembangkan diri, mengembangkan profesi, bekerja, usaha mandiri, dan/atau melanjutkan pendidikan ke jenjang yang lebih tinggi.

Salah satu jalur pendidikan yang ada di Indonesia yaitu jalur pendidikan nonformal. Pendidikan nonformal merupakan jalur pendidikan di luar pendidikan formal yang dilaksanakan secara terstruktur dan berjenjang. Menurut Undangundang No. 20 tahun 2003 tentang Sistem Pendidikan Nasional mengenai Jalur, Jenjang dan Jenis Pendidikan dalam Pendidikan Nonformal pasal (13) menyatakan bahwa:

"Pendidikan nonformal diselenggarakan bagi warga masyarakat yang memerlukan layanan pendidikan yang berfungsi sebagai pengganti, penambah, dan/atau pelengkap pendidikan formal dalam rangka mendukung pendidikan sepanjang hayat".

Fungsi dari pendidikan nonformal tersebut sangat tegas menyatakan bahwa dalam pelaksanaannya, pendidikan 
nonformal memang diselenggarakan untuk mendukung asas dari pendidikan sebagai penambah dan pelengkap bagi para peserta didiknya.

Salah satu lembaga pendidikan
nonformal yang sangat mendukung terselenggaranya asas pendidikan sebagai penambah dan pelengkap bagi peserta didik adalah LKP Lubuk Akal yang beralamatkan di J1. Flamboyan Raya No. 1B Kel. Kebun Kenangan Kec. Ratu Agung Kota Bengkulu.

Bahwa Lembaga Kursus dan Pelatihan (LKP) Lubuk Akal merupakan satu-satunya Lembaga Kursus Pelatihan (LKP) yang masih melaksanakan proses pengelolaan dan memiliki warga belajar serta masih melaksanakan kegiatan pembelajaran tatap muka seperti biasa pada masa pandemi COVID-19 ini.

Dalam menjalankan pengelolaan LKP dibutuhkan pemimpin atau manajer untuk memanajemen dan menjalankan tugas sesuai dengan fungsi manajemen secara efisien dan efektif. Dalam hal ini mengelola program pelatihan menjadi tanggung jawab semua pihak yang ada di suatu lembaga atau instansi dan membutuhkan suatu penanganan dan pengelolaan yang sangat serius.

Sesuai dengan pendapat Sudaryat (2010: 01) Manajemen pelatihan dimaksudkan sebagai proses penggunaan sumber daya secara efektif untuk mencapai sasaran yang berupa kegiatan melatih. Sebagai suatu proses, istilah manajemen pelatihan bergamitan dengan trisula aktivitas, yakni a) perencanaan, b) pengorganisasian, dan c) evaluasi.

Tahap-tahap dalam melaksanakan pengelolaan di LKP Lubuk Akal dilihat dari segi perencanaan pelatihan terdapat tujuan pelatihan, penetapkan struktur organisasi pengelola, tenaga pengajar atau pendidik, peserta didik, anggaran biaya dan sumber dana, waktu dan tempat, bahan ajar, metode yang digunakan fasilitas dan sarana prasaranan alat-alat dan bahan yang dibutuhkan dalam pelatihan. Dalam pelaksanaannya dilakukan pengorganisasian dan evaluasi yang tepat agar tujuan yang diharapkan dapat tercapai sesuai dengan rencana yang telah ditentukan.

Melihat pengelolaan yang tetap terlaksana di LKP Lubuk Akal selama masa pandemi sedangkan LKP lain pada masa pandemi ini tidak melaksanakan pengelolaan sama sekali. Maka peneliti tertarik dan ingin mendeskripsikan tentang pengelolaan Lembaga Kursus dan Pelatihan (LKP) Lubuk Akal Kota Bengkulu pada masa pandemi COVID- 19.

\section{METODE}

Penelitian ini merupakan jenis penelitian kualitatif yang bersifat deskriptif. Sugiyono (2016:9), mengemukakan bahwa metode penelitian kualitatif adalah metode penelitian yang digunakan untuk meneliti pada kondisi obyek yang alamiah dimana peneliti adalah sebagai instrumen kunci. Oleh karena itu, penelitian ini dilakukan secara kualitatif yang bertujuan untuk mendeskripsikan secara rinci dan mendalam mengenai pengelolaan lembaga kursus dan pelatihan terhadap LKP Lubuk akal yang menjadi LKP kursus menjahit satu-satunya yang masih aktif selama masa pandemi covid-19 ini 
Adapun deskripsi informan penelitian atau subjek penelitian dari penelitian ini yaitu:

1. Ibu Rosilah selaku ketua LKP

2. Bapak Erwin selaku ketua kurikulum

3. Ibu Leni Susanti Selaku Tutor.

Subjek pada penelitian ini telah dipilih dan ditetapkan oleh peneliti, sesuai dengan data dan informasi yang diperlukan dan subjek dianggap menguasai tujuan penelitian ini untuk menjawab permasalahan yang telah dirumuskan. Penelitian dilaksanakan dengan memfokuskan beberapa pertanyaan penting merujuk pada rumusan masalah yang diajukan kepada partisipan.

Penelitian ini dilakukan dalam waktu 2 minggu yaitu dimulai dari Kamis, 27 Januarisampai dengan 9 Februari 2021. Tempat dilaksanakannya penelitian secara umum adalah di LKP Lubuk Akal. Pelaksanaan penelitian ini bertujuan untuk membuktikan dan mendeskripsikan pengelolaan pembelajaran pada masa pandemi ini tetap dilakukan karena ketua LKP memiliki keberanian dan tanggung jawab untuk melaksakan pembelajaran tatap muka dengan mengutamakan protokol kesehatan.

Teknik pengumpulan data yang digunakan secara umum yaitu menggunakan: 1. teknik wawancara.

Menurut Saroso (2017:47)

wawancara adalah salah satu alat yang paling banyak digunakan untuk mengumpulkan data penelitian kualitatif. Wawancara memungkinkan peneliti mengumpulkandata yang beragam dari responden dalam berbagai situasi dan konteks. Meskipun demikian, wawancara perlu digunakan dengan berhati-hati dan perlu di triangulasi data dari sumber yang lain.

Wawancara dilakukan peneliti dengan alasan agar peneliti mampu mengajukan pertanyaan dengan bertatap muka langsung pada partisipan. Dengan penggunaan teknik wawancara, partisipan juga lebih bisa menyampaikan informasi secara langsung sehingga peneliti mampu mendapatkan jawaban lebih rinci dari pertanyaan-pertanyaan yang diajukan peneliti kepada partisipan.

\section{Teknik Observasi}

Menurut Fuad \& Sapto (2013 : 11) mendefinisikan observasi dalam penelitian kualitatif merupakan teknik dasar yang bisa dilakukan. Dalam awal penelitian kualitatif observasi sudah dilakukan saat grand tour observation. Metode observasi yang digunakan dalam bentuk pengamatan atau pengindraan langsung terhadap suatu benda, kondisi, situasi, proses atau perilaku.

Pada penelitian ini peneliti memilih pengumpulan data menggunakan teknik observasi secara partisipatif, sehingga peneliti mampu melakukan pengamatan terhadap kejadian yang terjadi serta melibatkan diri secara langsung pada pengumpulan data dan informasi yang dicari untuk menjawab pertanyaan yang menjadi permasalahan pada penelitian.

\section{Teknik Dokumentasi}

Menurut Fuad \& Sapto (2013 : 61) dokumentasi meruapakan salah satu sumebr data skunder yang diperlukan dalam sebuah penelitian. Studi siapkan karena adanya permintaan dari seorang peneliti. Selanjutnya studi dokumentasi dapat diartiakn sebagai teknik pengumpulan data 
melalui bahan-bahan yang tertulis yang di terbitkan oleh lembaga yang menjadi objek penelitian.

Peneliti menggunakan teknik dokumentasi pada pengumpulan data dengan alasan bahwa dengan dokumen, data yang diperlukan akan lebih mudah didapat dari tempat penelitian dan informasi melalui wawancara akan lebih nyata dibuktikan dalam bentuk dokumen.

Sedangkan untuk menguji keabsahan atau validitas data, maka peneliti menggunakan trianggulasi. Sugiyono (2017:273), mengartikan teknik pengumpulan data berupa trianggulasi diartikan sebagai teknik pengumpulan data yang bersifat menggabungkan dari berbagai teknik pengumpulan data dan sumber data yang telah ada. Adapun macam-macam trianggulasi yaitu

1. Trianggulasi subjek atau sumber penelitian, yaitu membandingkan hasil wawancara dan data hasil wawancara dengan cara mewawancarai sumber yang berbeda atau menggunakan minimal tiga atau lebih informan. Adapun subjek penelitian pada penelitian ini ada 3, yaitu tiga partisipan adalah Ibu Rosilah selaku ketua LKP, Bapak Erwin selaku ketua kurikulum dan ibu Leni susanti selaku tutor.

2. Trianggulasi waktu, yaitu melakukan proses pencarian informasi dengan melakukan penelitian dalam waktu yang berbeda pada subjek penelitian. Pada pelaksanaannya penelitian dilakukan pada waktu pagi, siang, dan sore.

3. Tririanggulasi teknik, yaitu penggunaan teknik pengumpulan data dengan menggunakan teknik yang berjumlah minimal tiga atau lebih teknik. Pada penelitian ini teknik yang digunakan yaitu wawancara, observasi dan dokumentasi.

Pada penelitian ini, peneliti melakukan analisis data, berupa:

1. Reduksi Data

Reduksi data diartikan sebagai proses pemilihan, pemusatan perhatian pada penyederhanaan, pengabstrakan, dan transformasi data "kasar" yang muncul dari catatan-catatan tertulis di lapangan. Dalam penelitian ini, peneliti mengumpulkan data dari berbagai hasil wawancara pada sumber penelitian.

2. Penyajian Data

Penyajian data dapat pula diartikan sebagai suatu proses pembuatan laporan mengenai hasil dari data dan informasi yang telah ditemukan oleh peneliti. Pada penelitian ini, peneliti mencoba menyajikan data yang berkaitan dengan hasil wawancara peneliti dengan sumber penelitian atas apa yang dianggap menjadi permasalahan pada penelitian.

3. Menarik Kesimpulan/ Verifikasi

Dalam penelitian ini, peneliti menarik kesimpulan pada data yang telah didapat dari hasil wawancara, observasi, dan dokumentasi dari Ibu Rosilah selaku ketua LKP, Bapak Erwin selaku ketua kurikulum dan Ibu Leni Susanti selaku tutor,

Kesimpulan-kesimpulan juga diverifikasi selama penelitian berlangsung. Verifikasi itu mungkin 
sesingkat pemikiran kembali yang melintas dalam pikiran penganalisis selama ia menulis, suatu tinjauan ulang pada catatan-catatan lapangan.

\section{HASIL DAN PEMBAHASAN}

Penelitian ini berlangsung di LKP Lubuk Akal yang beralamat di Jl. Flamboyan Raya No. 1B Kel Kebun Kenanga Kec Ratu Agung Kota Bengkulu. Berfokus pada pengelolaan LKP selama pandemi meliputi perencanaan, pengorganisasian dan penilaian.

perencanaan selama pandemi covid-19 di LKP Lubuk Akal yakni menyesuaikan kurikulum sebelum masa pandemi dengan menyesuaikan selama masa pandemi yang berupa pertemuan menjadi $2 \mathrm{x}$ dalam seminggu, membagi kelompok pertemuan yang terdiri dari 8 orang / kelas, tidak adanya perubahan instruktur dalam proses pembelajaran, perubahan jam kerja sesuai dengan perubahan jam tatap muka, dan penerapan protokol kesehatan dalam proses pembelajaran tatap muka dan saat pelaksanaan ujian kompetensi. Yang dalam proses penyesuaian kurikulum ini melibatkan Ibu Rosilah selaku ketua LKP, Bapak Erwin selaku pengatur kurikulum dan Ibu Leni Susanti selaku instruktur.

Pengorganisasian LKP selama pandemi covid juga tidak mengalami perubahan mendasar, pengelolanya tetap tidak berubah, instrukturnya juga tidak berubah, hanya jam kerjanya saja yang berubah, berubah diskusi antara ketua LKP dengan bapak Erwin selaku pengatur kurikulum untuk membagi pembagian tugas berdasarkan struktur pengorganisasian.
Penilaian selama masa pandemi mengalami sedikit perubahan, jujur saja standar keterampilan warga belajar agak sedikit berkurang karena kegiatan belajar praktek selama pandemi tidak seperti masa pandemi. Melihat keaktifan warga belajar dan melihat hasil dari ujian kompetensi yang sudah dilaksanakan, pada dasar penilaian pada masa pandemi ini sama dengan sebelum pandemi hanya saja pelaksanaan ujian kompetensinya menerapkan protokol kesehatan.

pengelolaan pembelajaran pada masa pandemi ini tetap dilakukan karena ketua LKP memiliki keberanian dan tanggung jawab untuk melaksakan pembelajaran tatap muka dengan mengutamakan protokol kesehatan.

Adapun hasil penelitian dari berbagai teknik pengumpulan data yaitu:

1. Wawancara

a. Cara yang dilakukan ketua LKP untuk melaksanakan pembelajaran tatap muka yakni melakukan rapat internal antara ketua LKP dan struktur organisasi untuk menentukan jadwal pembelajaran tatap muka dengan membagi dua kelompok wraga belajar.

b. Pengorganisasian dilaksanakan untuk menentukan jadwal tutor dalam mengajar.

c. Penilaian dilakukan menggunakan standar yang telah ditentukan oleh LKP seperti sebelum masa pandemi.

2. Observasi

Observasi pada Selasa 2 Februari 2021 pukul 11.00 WIB di LKP Lubuk Akal ruang administrasi 
bahwa berupa diskusi antara ketua LKP dan bapak Erwin, serta ibu Leni Susanti.

a. Observasi terhadap Rabu 3 Februari 2021 pukul 08.00 WIB di LKP Lubuk Akal ruang administrasi berubah diskusi antara ketua LKP dengan bapak Erwin selaku pengatur kurikulum untuk membagi pembagian tugas berdasarkan struktur pengorganisasian.

b. Jumat 29 Januari 2021 pukul 08.00 di ruang belajar LKP Lubuk Akal melihat proses pembelajaran tatap muka selama masa pandemi.

3. Dokumentasi

Pada teknik dokumentasi, peneliti menemukan data berupa Kurikulum, SOP Pengelolaan LKP selama masa Pandemi, absensi warga belajar, melihat hasil dari ujian kompetensi dan praktek.

\section{SIMPULAN}

Setelah dilaksanakan penelitian ini, berdasarkan data dan informasi yang diperoleh oleh peneliti berkenaan dengan pengelolaan LKP selama masa pandemi. Maka dapat disimpulkan bahwa:

1. perencanaan selama pandemi covid-19 di LKP Lubuk Akal yakni menyesuaikan kurikulum sebelum masa pandemi dengan menyesuaikan selama masa pandemi .

2. Pelaksanaan pengorganisasian LKP selama pandemi covid juga tidak mengalami perubahan mendasar, pengelolanya tetap tidak berubah, instrukturnya juga tidak berubah.

3. penilaian LKP Lubuk Akal selama masa pandemi berupa pelaksanaan penilaian selama masa pandemi mengalami sedikit perubahan.

Dengan dilaksanakannya penelitian dan melihat serta mempedomani hasil yang diperoleh, maka peneliti berharap dan merekomendasikan agar penelitian ini dapat bermanfaat sehingga semua LKP memiliki tanggung jawab memberikan materi pembalaran atau pelatihan terhadap peserta didik meskipun pada masa pandemi seperti saat ini dengan mengutamakan protokol kesehatan

Peneliti juga memberikan rekomendasi kepada peneliti selanjutnya, agar tetap memperhatikan komponenkomponen yang akan diteliti jika ingin melakukan penelitian lanjutan. Direkomendasikan untuk membahas secara rinci, khususnya padasemua LKP yang begerak di bidang pelatihan menjahit untuk melaksanakan pembelajaran tatap muka dengan mengutamakan protokol kesehatan.

\section{DAFTAR PUSTAKA}

Depdiknas (2003. Undang-undang RI No.20 tahun 2003 Tentang System Pendidikan

Nasional. Depdiknas. Jakarta.

Emzir. (2011). Metode Penelitian Kualitatif Analisis Data. Jakarta. Rajawali pers.

Fuad, Anis \& Sapto Kandung (2014). Panduan Praktis Penelitian Kualitatif. Yogyakarta. Graha Ilmu. 
Ikram. (2012). Lembaga Kursus dan Pelatihan. (bloganeuk pidie.blogspot.com).

Sudjana. H.D. (2004) Manajemen Program Pendidikan. Falah production. Bandung.

Sugiyono. 2016. Metode Penelitian Kuantitatif, Kualitatif dan $R \& D$. Bandung: PT Alfabet.

Yayat,Sudaryat. (2010). Manajemen Pelatihan. Hlm 1-

Menyelenggarakan Program Pendidikan Berbasis Masyarakat. Media Ekonomi dan Manajemen, 32(2).

Muhtar, Fathurrahman, and Siti Hajaroh. "Pemberdayaan pemuda desa melalui budi daya jamur tiram di Desa Lembah Sempage Narmada Lombok Barat." Transformasi: Jurnal Pengabdian Masyarakat 12.2 (2016): 157-167. 20840-ID-teknik-focusgroup-discussion-dalam-penelitiankualitatif.pdf

Suharto, T. (2005). Konsep dasar pendidikan berbasis masyarakat. Jurnal Cakrawala Pendidikan, (3).

http://repository.uinsu.ac.id/8602/1/Skripsi.p df

http://jurnal.umtapsel.ac.id/index.php/muqoddimah/ article/view/279

https://safiraspd.blogspot.com/2016/10/peng ertian-pendidikan-masyarakatdan.html\#: :text=Pendidikan\%20Ma syarakat $\% 20$ diartikan $\% 20$ sebagai $\% 2$ Olayanan,meningkatkan\%20kompete nsi\%20untuk\%20meningkatkan $\% 20$ kesejahteraan 